\title{
IMPLEMENTASI ETIKA BISNIS SYARIAH DALAM UPAYA MENINGKATKAN DAYA SAING UMKM DI KEBUPATEN TANGERANG
}

\author{
Maskur Rosyid ${ }^{1}$ \\ Eka Pratiwi ${ }^{2}$ \\ ${ }^{1}$ Universitas Islam Negeri Walisongo Semarang \\ ${ }^{2}$ Sekolah Tinggi Ekonomi Syariah Islamic Village (STES) Tangerang \\ Email: masykurxrejo@gmail.com, ekapratiwi0620@gmail.com
}

\begin{abstract}
This study is aimed to find out the implementation's effect of sharia business ethics of micro-small business owners in order to enhance the competitiveness of their businesses in Panongan Tangerang. This study uses a qualitative analysis method in which to collect the data, interviews and observations conducted in this research. the Findings of this study are the Micro-Small Businesses' Owners in Panangon has been implementing the sharia business ethics in their daily activities such as: ikhlas (sincere), amanah (trusty), shidiq (honest), syirkah (cooperative). The implementation of Islamic ethics in their businesses affects to enhancing the competitiveness and in the long term increasing the business owners in Panongan.
\end{abstract}

Keywords : UMKM, Competitiveness and Business Ethics

\section{PENDAHULUAN}

Aktivitas ekonomi manusia yang bertujuan untuk memperoleh laba disebut dengan Bisnis. Kegiatan bisnis sangat berkaitan dengan persaingan, sebab persaingan dibutuhkan oleh pelaku bisnis untuk memaksimalkan tingkat penjualan dan menghadapi kehadiran kompetitor yang bergerak di bidang penjualan yang sama. Ajaran Islam menganjurkan umatnya untuk berlomba - lomba dalam kebaikan. Ajaran Islam juga menganjurkan umatnya untuk melaksanakan segala aktivitas bisnis dengan sistem persaingan yang sehat. Jika hal tersebut dijadikan dasar bisnis maka praktek bisnis harus dilaksanakan dengan aktivitas persaingan yang sehat dan mengandung kebaikan. Selain itu, persaingan bisnis juga diharapkan dapat memberikan kontribusi yang baik bagi pelakunya. Dalam persaingan usaha hendaknya ada komitmen bersama diantara para pelaku bisnis untuk menerapkan konsep persaingan bisnis, dengan tidak lagi mengartikan bahwa suatu persaingan hanya dapat dilakukan dengan cara mematikan usaha pesaing bisnis, namun mengartikan suatu persaingan sebagai cara untuk memberikan sesuatu yang terbaik dari usaha bisnisnya dan yang berbeda dari yang lainnya sehingga usaha bisnisnya memiliki keunggulan dibandingkan usaha bisnis milik orang lain.

Bisnis mencakup berbagai jenis usaha termasuk usaha mikro, kecil, dan menengah (UMKM). Setiap UMKM memiliki prinsip dan pemikiran yang berbeda terhadap perkembangan dan kemajuan usahanya. Sebagian besar para pelaku UMKM memiliki kelemahan dalam meningkatkan kemampuan usaha, diantaranya; permodalan (sumber modal dan jumlah modal), minimnya kemampuan dalam manajerial dan keterampilan dalam mengorganisir serta pemasaran yang terbatas. Adapun faktor lain yang juga menjadi kelemahan bagi pelaku UMKM yaitu, maraknya persaingan yang kurang sehat dan ekonomi yang menyebabkan ruang lingkup usaha menjadi sempit dan terbatas.

Berdasarkan latar belakang tersebut, etika bisnis merupakan solusi yang tepat untuk menjawab berbagai permasalahan dalam persaingan bisnis yang semakin memanas di kalangan para pelaku bisnis. Oleh sebab itu, peneliti bertujuan untuk meneliti penerapan etika bisnis yang berkaitan dengan tingkat daya saing UMKM khususnya di bidang makanan yang berlokasi di Kecamatan Panongan Kabupaten Tangerang. 


\section{Implementasi}

\section{TIANJAUAN LITERATUR}

Menurut Kamus Besar Bahasa Indonesia (KBBI), pengertian implementasi adalah pelaksanaan; penerapan (KBBI). Sementara menurut Wheelen dan Hunger, implementasi merupakan suatu proses untuk menempatkan dan menerapkan informasi dalam operasi. Adapun menurut Van Meter dan Van Horn, implementasi adalah pelaksanaan oleh tindak individu, pejabat, instansi pemerintah, maupun kelompok swasta dengan tujuan untuk menggapai cita-cita yang telah digariskan dalam keputusan tertentu (Muntaha, 2016). Menurut Mulyadi (2015), implementasi mengacu pada tindakan untuk mencapai tujuan-tujuan yang telah ditetapkan dalam suatu keputusan (Apriandi, 2017).

\section{Etika Bisnis Syariah}

Etika bisnis syariah adalah nilai-nilai akhlak budi pekerti yang baik dan mulia dalam rangkaian tingkah laku manusia melakukan aktivitas bisnis yang berdasarkan pada panduan ajaran Agama Islam. Etika bisnis syariah dibungkus dengan batasan-batasan halal dan haram tidak sepeti etika bisnis konvensional. Karena halal dan haramnya yang membedakan antara pengusaha yang muslim dan non muslim (Rachman, 2017).

Islam menjelaskan berbagai etika ataupun akhlak yang harus dilakukan oleh pengusaha muslim dalam melaksanakan jual beli. Etika ataupun akhlak akan memacu perkembangan bisnis untuk dapat berkembang pesat karena adanya keberkahan yang diberikan Allah SWT ketika mengimplementasikan etika. Etika bisnis syariah merupakan tata nilai dan norma dalam menjalankan bisnis berdasarkan pada ajaran Agama Islam yang bersumber dari Al-Qur'an dan As-Sunnah. AlQur'an sebagai sumber utama etika bisnis memberikan tuntutan konsep keadilan, perlindungan, kebebasan yang bertanggung jawab dan lain sebagainya (Rachman, 2017).

\section{Daya Saing}

Daya saing adalah usaha serta kemampuan dari sebuah perusahaan untuk memberikan nilai lebih kepada produk yang dihasilkan dan mendapatkan nilai lebih dari konsumen karena harga jual yang tinggi dan manfaat dari produk tersebut. Dalam dunia usaha daya saing tampak pada kualitas pelayanan kepada konsumen itu sendiri (Rukmanasari, 2017). Daya saing merupakan kemampuan suatu komiditi untuk memasuki pasar luar negeri dan kemampuan untuk dapat bertahan dalam pasar tersebut (Wardani, et.al 2017).

\section{UMKM}

UMKM adalah singkatan dari Usaha Mikro, Kecil, dan Menengah. Sehingga UMKM terdiri dari tiga bentuk usaha berdasarkan skalanya, yaitu meliputi; Usaha Mikro, Usaha Kecil dan Menengah. Berikut adalah pengertian dari ketiganya yang didasarkan pada Undang-undang Nomor 20 Tahun 2008, yakni sebagai berikut; (Undang-undang Nomor 20 Tahun 2008).

1. Usaha Mikro adalah usaha produktif milik orang perorangan dan/atau badan usaha perorangan yang memenuhi kriteria; memiliki kekayaan bersih paling banyak Rp.50.000.000,- dan hasil penjualan paling banyak Rp. 300.000.000,-

2. Usaha Kecil adalah usaha ekonomi produktif yang berdiri sendiri, yang dilakukan oleh orang perorangan atau badan usaha yang bukan merupakan anak perusahaan atau bukan cabang perusahaan yang dimiliki, dikuasai, atau menjadi bagian baik langsung maupun tidak langsung dari usaha menengah atau usaha besar yang memenuhi kriteria; memiliki kekayaan bersih lebih dari Rp.50.000.000,- sampai Rp. 500.000.000,- dan hasil penjualan paling banyak Rp. 300.000.000,sampai Rp.2.500.000.000,-

3. Usaha Menengah adalah usaha ekonomi produktif yang berdiri sendiri, yang dilakukan oleh orang perorangan atau badan usaha yang bukan merupakan anak perusahaan atau cabang perusahaan yang dimiliki, dikuasai, atau menjadi bagian baik langsung maupun tidak langsung dari usaha menengah atau usaha besar yang memenuhi kriteria; memiliki kekayaan bersih lebih dari Rp. 500.000.000,- sampai dengan Rp.10.000.000.000,- dan hasil penjualan paling banyak Rp.2.500.000.000,- sampai dengan Rp.50.000.000.000,- 


\section{Kerangka Pemikiran}

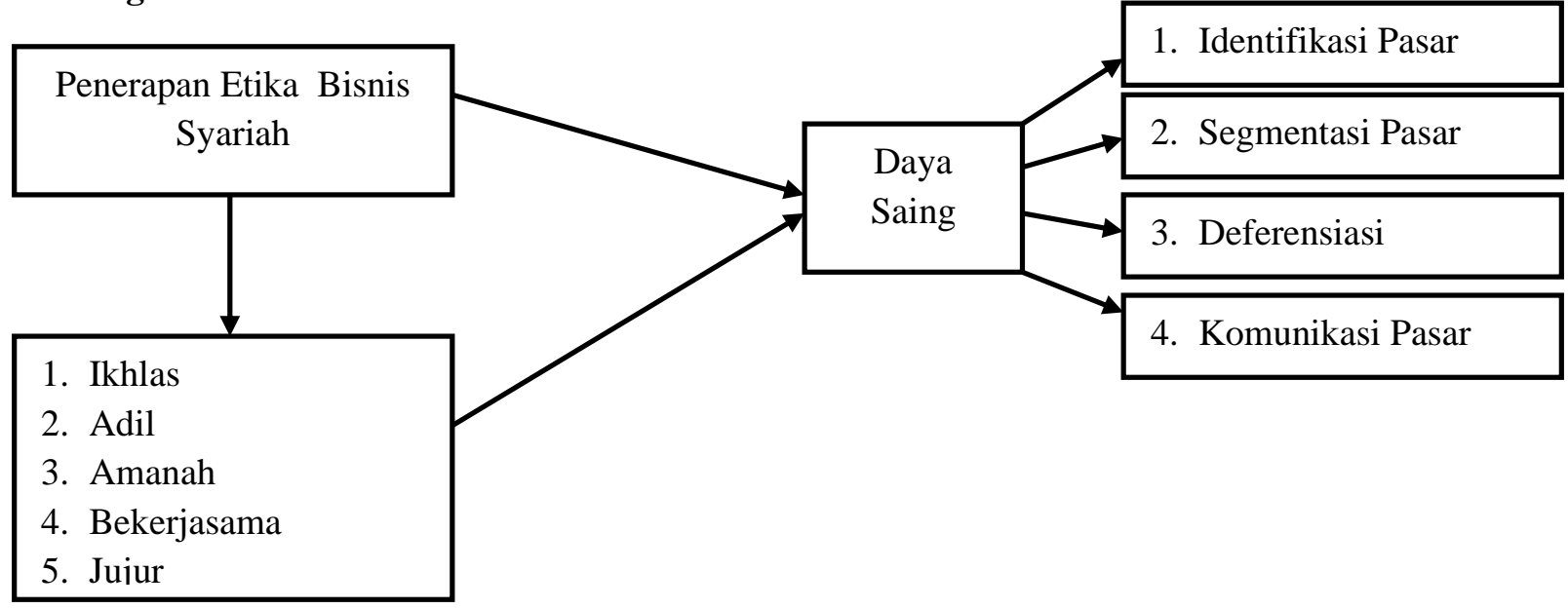

Peneliti mengukur penerapan etika bisnis syariah pelaku UMKM di Kecamatan Panongan dengan lima indikator, yaitu; ikhlas, adil, amanah, bekerjasama dan jujur. Lima indikator tersebut yang akan peneliti kaitkan kembali dengan tingkat daya saing UMKM di Kecamatan Panongan melalui empat indikator, yaitu; identifikasi pasar, segmentasi pasar, deferensiasi, dan komunikasi pasar.

\section{METODE PENELITIAN}

Metode yang digunakan dalam jurnal ini adalah metode kualitatif. Metode kualitatif sering disebut metode penelitian naturalistik karena penelitian dilakukan terhadap objek dalam kondisi yang alamiah atau apa adanya. Peneliti dalam hal ini melakukan penelitian langsung melalui teknik survey terhadap pelaku UMKM yang bergerak di bidang makanan dan berlokasi di Desa Panongan, Desa Serdang Kulon, dan Desa Ciakar, Kecamatan Panongan. Teknik pengumpulan data juga peneliti lakukan dengan cara observasi, wawancara; wawancara terstruktur, dan dokumentasi. Sementara, data yang telah diperoleh, akan peneliti analisis menggunakan teknik analisis data; pengumpulan data, reduksi data, penyajian data, dan kesimpulan.

\section{Impelementasi Etika Bisnis Syariah}

\section{HASIL DAN PEMBAHASAN}

Suatu bisnis tidak akan lengkap tanpa adanya etika yang yang diterapkan. Ini berarti bahwa semua orang khususnya pelaku usaha harus memiliki etika dan berupaya untuk memperkaya atau memperbaiki diri dengan ilmu pengetahuan, sebab dalam melaksanakan bisnis apapun, etika sangat dibutuhkan. Pelaku bisnis yang sukses juga merupakan pelaku bisnis yang berperilaku mulia dan mempunyai sikap yang positif, seperti yang telah dicontohkan oleh Rasulullah saw. Sikap yang harus dimiliki oleh pelaku bisnis diantaranya; pandai bersyukur, ikhlas, adil, bekerjasama, amanah dan jujur. Dengan demikian pelaku bisnis akan memiliki sifat kretif dan inovatif.

Ikhlas dalam melakukan usaha, dan adil terhadap konsumen (tidak ada istilah membedabedakan antara konsumen satu dengan yang lainnya) sehingga dapat tercipta atau membangun loyalitas terhadap konsumen. Bekerjasama dengan relasi bisnis yang lain atau dengan reseller merupakan upaya mengembangkan produk supaya produk semakin dikenal baik di pasaran maupun sampai ke luar daerah. Amanah merupakan hubungan yang tidak hanya melibatkan manusia saja melainkan dengan Allah SWT. Hal ini berarti bahwa segala apapun bentuk amanah yang diterapkan akan mendapatkan dua keuntungan yaitu keuntungan yang akan diberikan oleh manusia dan diberikan oleh Allah SWT. Jujur berarti bahwa pelaku bisnis tidak berbohong dalam setiap aspek produksi, pemasaran, distribusi, bahkan konsumsi.

Para pelaku UMKM di Kecamatan Panongan, sudah menerapkan etika bisnis syariah, salah satunya Bapak H. Musa yang memiliki usaha dodol. Hal tersebut sebagaimana diungkapkan oleh salah seorang Aparat Desa Serdang Kulon yang menyampaikan bahwa sebagian besar pelaku UMKM di Kecamatan Panongan telah mengetahui etika bisnis syariah dan telah menerapkannya. Sebab, etika bisnis syariah sangat penting untuk diterapkan dalam melaksanakan suatu bisnis (Mamih, 2019). 
Penerapan etika bisnis syariah juga telah diterapkan dan diakui sendiri oleh para pelaku UMKM di Kecamatan Panongan, seperti yang disampaikan oleh Bapak Samsul, salah satu pelaku UMKM di Kecamatan Panongan yang memiliki usaha dodol (Samsul, 2019).

\section{Implementasi Etika Bisnis dalam Meningkatkan Daya Saing}

Suatu usaha tidak pernah lepas dengan namanya persaingan, aktivitas persaingan bukanlah hal yang asing dalam berbisnis. Dengan ini penerapan etika bisnis syariah dapat meningkatkan daya saing dan sangat berpengaruh terhadap persaingan. Daya saing memiliki empat indikator yang terdiri dari; identifikasi pasar, segmentasi pasar, deferensiasi, dan komunikasi pasar.

1. Identifikasi Pasar, pelaku usaha harus lebih memperhatikan harga, kualitas, dan mutu barang yang akan dipasarkan. Hal tersebut sebagaimana disampaikan oleh Bapak Basuki, salah satu pelaku UMKM di Kecamatan Panongan yang memiliki usaha Keripik Tempe. Beliau menyampaikan bahwa pemilihan kualitas tempe menjadi hal utama yang harus dilakukan sebelum melakukan penjualan produk keripik tempe (Basuki, 2019).

2. Segmentasi Pasar, terdapat beberapa kelompok pelaku UMKM yang membedakan pasar berdasarkan kebutuhan, karakteristik atau tingkah laku, yang mungkin membutuhkan produk yang berbeda. Seperti; Ibu Nurhasanah yang memilih bahan baku produk yang berbeda dari yang lainnya, yaitu dari kunyit yang diperoleh kebun (Nurhasanah, 2019).

3. Deferensiasi, menyediakan nilai - nilai unik dan superior kepada pelanggan dari sisi kualitas atau ciri khusus. Salah satu pelaku UMKM di Kecamatan Panongan, Ibu Nurhasanah menyampaikan bahwa nilai unik atau ciri khusus dari suatu produk (deferensiasi) sangat penting untuk diterapkan sebagai upaya dalam meningkatkan daya saing usaha (Nurhasanah, 2019).

4. Komunikasi Pasar, melakukan komunikasi dengan konsumen dapat menyadari dan memahami keberadaan produk jasa yang ditawarkan. Bapak Samsul, salah satu pelaku UMKM di Kecamatan Panongan yang memiliki usaha dodol menyampaikan bahwa beliau dan konsumen-nya akan bermusyawarah untuk mencari jalan tengah dari kritik atau complain yang disampaikan oleh konsumennya. Hal tersebut menunjukkan bahwa komunikasi pasar telah diterapkan oleh pelaku UMKM di Kecamatan Panongan (Samsul, 2019).

Hasil penelitian ini, menunjukkan bahwa implementasi etika bisnis syariah telah diterapkan oleh pelaku UMKM di Kecamatan Panongan sehingga pelaku UMKM di Kecamatan Panongan memiliki peluang untuk meningkatkan daya saing di Kecamatan Panongan. Hasil ini memiliki hasil yang serupa oleh penelitian Titik Pramitasari mengenai Implementasi Etika Bisnis dalam Menghadapi Persaingan Bisnis. Beliau menyampaikan bahwa home industries tenun tikar Nies Collection mampu menghadapi persaingan dengan cara menerapkan etika bisnis yang terdiri dari; tauhid, keseimbangan, kebebasan, dan tanggungjawab (Pramitasari, 2019).

Adapun penelitian Ismatul Chalimah, mengenai Implementasi Etika Bisnis Islam dalam Persaingan Para Penjual, beliau juga menyampaikan bahwa penerapan etika bisnis; mengedepankan prinsip kebaikan seperti prinsip halal dan haram, menguatamakan kualitas produk yang baik serta mengedepankan sikap ramah tamah, menjadikan Toko Al-Araffah memiliki kemampuan untuk memenangkan persaingan dalam penjualan produk (Chalimah, 2017). Hal ini juga memiliki kesamaan dengan hasil penelitian Utari Evy Cahyani mengenai Strategi Bersaing dalam Berbisnis secara Islami, menyampaikan bahwa tugas manusia untuk memperoleh rezeki adalah dengan cara yang baik-baik, termasuk dalam pelaksanaan persaingan bisnis Islam; seorang pelaku bisnis tidak boleh merasa takut kehilangan rezeki dengan memiliki anggapan bahwa rezeki tersebut akan diambil oleh pesaingnya (Cahyani, 2017).

\section{KESIMPULAN}

Peneliti menyimpulkan bahwa pelaku UMKM yang berlokasi di Kecamatan Panongan sudah menerapkan etika bisnis Islam dan mengetahui bahwa etika bisnis Islam (seperti; ikhlas, adil, amanah, bekerjasama dan jujur) sangat penting untuk diterapkan dalam melaksanakan usahanya. Pelaku UMKM di Kecamatan Panongan juga menyadari bahwa etika bisnis syariah yang diterapkan dapat meningkatkan daya saing produk UMKM di pasaran. Hal ini dikarenakan, suatu yang dijalankan dengan menerapkan prinsip syariat Islam akan menghasilkan hasil yang baik bagi kehidupan termasuk dalam meningkatkan daya saing bagi UMKM. 


\section{DAFTAR PUSTAKA}

Ayu Wardani, Mia dan Sri Mulatsih.2017.Analisis Daya Saing dan Faktor-faktor yang Mempengaruhi Ekspor Ban Indonesia ke Kawasan Amerika Latin.Jurnal Ekonomi dan Kebijakan Pembangunan. 2019.

Basuki.2019.Wawancara Bapak Basuki ( Usah Keripik Tempe ).Handphone Oppo A5s, 25 Juni

Chalimah, Ismatul .2017.Implementasi Etika Bisnis Islam dalam Persaingan Para Penjual: Studi Kasus Toko Grosir Al-Araffah Pasar Wage Purwokerto. IAIN Purwokerto, Purwokerto.
Kamus
Besar
Bahasa
Indonesia
Online.t.t.KBBI;
Implementasi, https://www.kbbi.web.id/implementasi.diakses: 05/12/20 pukul 06:52 WIB.

Mamih.2019.Wawancara Ibu Mamih ( Aparata Desa Serdang Kulon ).Handphone Oppo A5s, 2 Juli 2019.

Muntaha, Sidrotul.2020.Apa yang dimaksud dengan Implementasi?, https://www.alihamdan.id/implementasi/.diakses: 05/12/20 pukul 06:58 WIB.

Nurhasanah.2019. Wawancara Ibu Anah ( Usaha Tahu Kabita ).Handphone Oppo A5s, 27 Juni 2019.

Pramitasari, Titik.2019.Implementasi Etika Bisnis dalam Menghadapi Persaingan Bisnis: Studi Pada Home Industries Tenun Tikar Nies Collection.UIN Sunan Ampel, Surabaya.

Presiden Republik Indonesia.2008.Undang-undang Nomor 20 Tahun 2008.www.bi.go.id, diakses: 05/12/20 pukul 07:41 WIB.

Rachman, Abdul.2014.“Etika Bisnis Syariah,” Dinas Pendidikan Provinsi Banten. 2019.

Samsul, Wawancara Bapak Samsul ( Usaha Dodol Pak Oyot ).Handphone Oppo A5s, 26 Juni

Umie Rukmanasari, Sulistya.2017."Manajemen Strategi Dalam Meningkatkan Daya Saing Pendidikan," J-PAI 3, no. 1 (18 Januari 2017): 38, https://doi.org/10.18860/j-pai.v3i1.3990.

Evy Cahyani, Utari.2016.Strategi Bersaing dalam Berbisnis secara Islami, IAIN Padangsidimpuan. 